\title{
EDITORIAL \\ MANAGING HEART FAILURE WITH REDUCED EJECTION FRACTION: WHAT TO KNOW?
}

\author{
Tariq Ashraf ${ }^{1}$, Muhammad Ishaq ${ }^{1}$ \\ ${ }^{1}$ Karachi Institute of Heart Diseases, Karachi, Pakistan
}

The estimated population of congestive heart failure (CHF) patients in Pakistan is 28 millions. ${ }^{1}$ Besides epidemics of type 2 diabetes mellitus and coronary heart disease, South Asian countries are also be at an increased risk of heart failure at earlier ages than other racial/ethnic groups. ${ }^{2}$ Heart failure sub classified into three categories:

1) With preserved ejection fraction ( $\mathrm{LVEF}>50 \%)$,

2) Mid-range ejection fraction (LVEF41-49\%),

3) Reduced ejection fraction $(\mathrm{LVEF}<40 \%))^{3}$

According to studies in United States of American (USA) and United Kingdom (UK) ${ }^{4,5}$ heart failure with reduced ejection fraction (HFrEF) prevalence has increased due to ageing population, improved survival from myocardial infarction and high prevalence of co-morbid conditions like diabetes and obesity. With increasing number of young patients $(<40$ years $)$ with acute myocardial infarction (AMI) $12 \%^{6}$ in our population, prevalence of heart failure with predisposing factors need to be explored.

Other than diagnosing and work up of these patients, the most challenging part is the pharmacological treatment by therapeutic agents proven to reduce morbidity and mortality in HRrEF. Registries have shown under-usage of angiotensinconverting enzyme (ACE) inhibitors, angiotensin II receptor blockers (ARBs), angiotensin receptorneprilysin inhibitor (ARNI), Beta-blockers and mineralocorticoid receptor antagonists (MRA) in such patients. ${ }^{7}$ Reason of not acheving the outcomes were due to not attaining the target levels of drugs dosages. $^{8}$

With recommendations from new guidelines new novel drug therapies i.e. sodium-glucose cotransporter-2 (SGLT2) inhibitors, most debatable questions from the physicians are keeping in view the hemodynamic status and kidney function. Questions coming to the Physicians minds include ${ }^{9}$

1) Should all guideline directed medical therapies be started together or stage wise?

2) Which drugs should be titrated first?

3) How quick can one up-titrate B-blockers and ARNI?
4) At what level of kidney impairment should one stop ACE/ARB/ARNI/SGLT2 inhibitors?

5) When should one refer these patients for cardiac resynchronization therapy device (CRTD) or Heart Transplantation?

6) When should one repeat transesophageal echocardiography (TEE)?

Physicians need to have clear answers and stance on the above queries.

HFrEF is a major public health concern in our population especially with early onset of ischemic heart disease (IHD). Awareness, education and up to date knowledge regarding early diagnosis, work up and adjustments of drugs in such patients with proper follow up is important to reduce the ever rising morbidity and mortality in our population.

Conflict of interest: Authors declared no conflict of interest.

\section{REFERENCES}

1. Sheikh SA. Heart failure in Pakistan: A demographic survey. J Card Fail. 2006;12(8):S157.

2. Martinez-Amezcua P, Haque W, Khera R, Kanaya AM, Sattar N, Lam CS, et al. The upcoming epidemic of heart failure in South Asia. Circ Heart Fail. 2020;13(10):e007218.

3. Yancy CW, Jessup M, Bozkurt B, Butler J, Casey Jr DE, Colvin MM, et al. 2017 ACC/AHA/HFSA focused update of the 2013 ACCF/AHA guideline for the management of heart failure: a report of the American College of Cardiology/American Heart Association Task Force on Clinical Practice Guidelines and the Heart Failure Society of America. J Am Coll Cardiol. 2017;70(6):776-803.

4. Virani SS, Alonso A, Benjamin EJ, Bittencourt MS, Callaway CW, Carson AP, et al. Heart disease and stroke statistics - 2020 update: a report from the American Heart Association. Circulation. 2020;141(9):e139-596.

5. Mozaffarian D, Benjamin EJ, Go AS, Arnett DK, Blaha MJ, Cushman M, et al. Heart disease and stroke statistics - 2015 update: a report from the 
American Heart Association. Ccirculation. 2015;131(4):e29-322.

6. Batra MK, Rizvi NH, Sial JA, Saghir T, Karim M. Angiographic Characteristics and in Hospital Outcome of Young Patients, Age Up to 40 Versus More Than 40 Years Undergoing Primary Percutaneous Coronary Intervention. J Pak Med Assoc. 2019;69(9):1308-12.

7. Greene SJ, Butler J, Albert NM, DeVore AD, Sharma PP, Duffy CI, et al. Medical therapy for heart failure with reduced ejection fraction: the
CHAMP-HF registry. J Am Coll Cardiol. 2018;72(4):351-66.

8. Konstam MA, Neaton JD, Dickstein K, Drexler H, Komajda M, Martinez FA, et al. Effects of high-dose versus low-dose losartan on clinical outcomes in patients with heart failure (HEAAL study): a randomised, double-blind trial. Lancet. 2009;374(9704):1840-8.

9. Murphy SP, Ibrahim NE, Januzzi JL. Heart failure with reduced ejection fraction: a review. JAMA. 2020;324(5):488-504.

Citation: Ashraf T, Ishaq M. Managing Heart Failure with Reduced Ejection Fraction: What to Know?. Pak Heart J. 2021;54(03):205-206. https://doi.org/10.47144/phj.v54i3.2192

\section{Address for Correspondence:}

Dr. Tariq Ashraf, Karachi Institute of Heart Diseases, Karachi, Pakistan

Email: tariqash45@gmail.com 